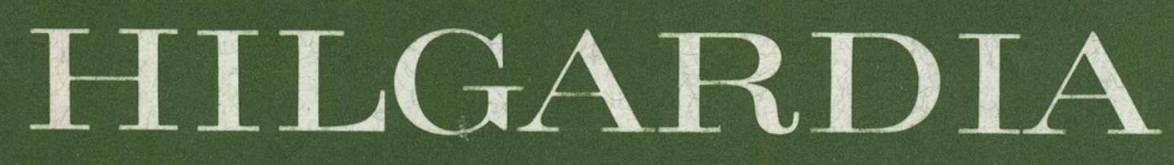

A JOURNAL OF AGRICULTURAL SCIENCE PUBLISHED BY THE CALIFORNIA AGRICULTURAL EXPERIMENT STATION

Volume 42, Number 9·April, 1974

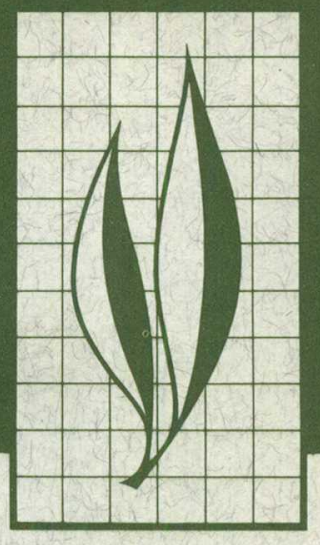

\title{
Studies on the Origin of the Lemon
}

M.N. Malik, R. W. Scora, and R. K. Soost 

with the orientation of the photograph. To read correctly, the photo should be turned 90 degrees clockwise with the rule at the bottom.

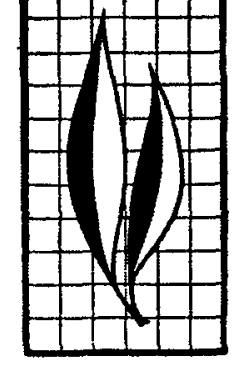

Hybrids of 'Eureka' and 'Lisbon' lemons were studied along with their parents and possible ancestral types to investigate the phylogeny of Citrus limon (L.) Burm. f. Data on leaf, flower, and fruit characters were collected and analyzed for inheritance of specific characters and for the amount of variability. Leaf and rind-oil components were analyzed by gas chromatography. Those hybrids producing sufficient microspores were studied for meiotic abnormalities. Segregation of all characters studied demonstrates the heterozygosity of $C$. limon. Color (anthocyanin) development in flower buds and young leaves is most likely controlled by a single dominant gene. Color on the young stems may be controlled by two dominant genes, one of which also controls color in flower buds and young leaves. Preformed root initials are most likely controlled by one, and leaf articulation by at least two genes.

Characters specific to $C$. medica were present in the lemon progeny, indicating definite involvement of the citron in the lemon ancestry. Some characters indicate a possible common gene source with $C$. aurantifolia and $C$. jambbiri. The deviation of some hybrids from their parents or proposed ancestors indicates a contributing gene source that has not yet been identified.

The presence of much sterility and wide segregation of characters argues against the specific standing of $C$. limon. It has a common gene source with the citron-lime group, and it may be a derived hybrid involving some unidentified taxa.

The overlapping geographical distribution of various Citrus taxa at the assumed place of origin of $C$. limon further suggests the possibility of intercrossing or common origin of various Citrus species.

\section{THE AUTHORS:}

M. N. Malik is in the Department of Horticulture, West Pakistan Agricultural University, Lyallpur, Pakistan. He was formerly a graduate student of Department of Plant Sciences, Riverside.

R. W. Scora is Associate Professor of Botany and Associate Botanist in the Experiment Station, Riverside.

R. K. Soost is Professor of Genetics and Geneticist in the Experiment Station, Riverside. 


\section{Studies on the Origin of the Lemon ${ }^{1}$}

\section{INTRODUCTION}

THE ORIGIN OF THE LEMON-Citrus limon (L.) Burm. f. of the family Rutaceae in the subfamily Aurantioideaehas been a source of prolonged disagreement and often conflicting statements by both historians and taxonomists. Although Bonavia (1888) and several other authorities concluded that the lemon reached India relatively late, Tolkowsky (1938) believed it to be a fruit mentioned in early Sanskrit texts assigned to the period 800 B.C. The most recent summary of conflieting historical data on the geographical origin of the lemon may be found in Webber, Reuther, and Lawton (1967), who suggest southern China or possibly upper Burma as the native home of the lemon. Much of the dispute eenters on the fact that historical sources are rarely preeise in pomological descriptions and may refer only to fruits that resemble the lemon or which are hybrids.

Even the taxonomic classification of the lemon offers problems, since considerable controversy exists over Citrus taxonomy generally. A high frequency of intercrossing of various citrus forms, a long period of hybridization, and the presence of nucellar embryony result in the production of many stable taxa. The number of species varies greatly within the genus Citrus according to different taxonomists. Marcovitch (1926), whose classification is based on foliage and flora characteristics, lists 20 species; Swingle (1943) listed 16 species based on morphological characteristics of plants and fruits; Hodgson (1961) added 20 additional species to Swingle's list; and Tanaka (1969a) recognized 159 species on the basis of morphological differences among plants and fruits.

Early taxonomists hypothesized that C. limon was a derivative or hybrid of C. medica L., the citron. Gallesio (1876) noted that during the middle ages the lemon was looked upon as a variety of the citron. De Candolle (1886) considered the lemon to be closely related to the citron. Jewish and Arab medical writers in the middle ages occasionally called the lemon a citron (Tolkowsky, 1938). Linnaeus (1753) and other early writers included both the lemon and the lime with the citron in the species $C$. medica L. Subsequent authorities such as Risso (1813), Michel (1816), Lushington (1910), Swingle (1914, 1943), Tanaka (1954), and Bhattacharya and Dutta (1956) gave separate specific names to both the citron and lemon. Swingle (1914) isolated the citron as C. medica, lime as $C$. aurantifolia, and lemon as C. limonia Osbeck, but in 1943 he reclassified the lemon as $C$. limon. Swingle considered the lemon to be a probable satellite species of the citron and further suggested that it might prove to be of hybrid origin, perhaps having the citron and lime as parent species. Hodgson (1955) put the citron, the

\footnotetext{
${ }^{1}$ Submitted for publication December 4, 1973.
} 
lemon, and the lime into one group. In summary, although many major taxonomists have given specific rank to the lemon, they also have had reservations concerning such ranking.

In recent years, chemical plant components have shown promise as additional characteristies for taxonomic and phylogenetic investigations. Essential oils are particularly well suited for such studies because of their distribution in many plant families and their wide chemical diversity. Kesterson et $a l$. (1964), Pieringer, Edwards, and Wolford (1964), and Scora, Duesch, and England (1969) have shown that essential oils in Citrus and related genera are reliable characteristics that can be used as additional aids for Citrus systematics.

In the present studies, leaf and rind oils of parent 'Eureka' and 'Lisbon' lemon cultivars and their hybrid prog- enies were analyzed along with the possible ancestral cultivars 'Indian' lime, 'Yemen' eitron, and 'Spadifora' citron.

In addition to leaf and rind-oil studies, specific characters were studied in the parents, in proposed ancestral types, and in progenies. Pollen fertility and meiosis were also examined in those progeny plants that flowered. Fruit characteristics were compared in those few individuals that fruited.

Our objective was to determine the taxonomic relationship between $C$. limon and the gene sources contributing to it. It has not been possible to obtain acceptable lemon-like fruits by either hybridization within $C$. limon or crossing with several other species. The determination of gene sources contributing to $C$. limon could aid efforts to breed lemon-like fruits.

\section{MATERIALS AND METHODS}

These studies were earried out on previously established citrus plantings at three locations: the Citrus Research Center and Agricultural Experiment Station, University of California, Riverside, California; the U.S. Date and Citrus Station, Indio, California; and the University of California South Coast Field Station, Irvine, California.

Two varieties of Citrus medica L., one variety of $C$. aurantifolia (Christm.) Swing., two varieties of $C$. limon (L.) Burm. f., 100 intraspecifie hybrid plants of $C$. limon from crosses made at Riverside in 1954-55 between two clones (Ross and Meek) of Eureka lemon ( $C$. limon), and the following five clones of Lisbon lemon $(C$. limon)-Monroe, Rosenberger, Prior, Ledig, and Galligan-were available for study. The hybrids had been established during 1957-1959 on two rootstocks: sweet orange and Cleopatra mandarin.

For leaf-oil analysis, leaves were harvested from one tree each of a
Eureka and Lisbon lemon parent, one each of 40 hybrid trees of Eureka $x$ Lisbon, and from one tree each of Indian lime and Yemen and Spadifora citron. Harvests were made in October, 1968, and in October, 1969. About 300 healthy, mature leaves were selected from the four sides of each plant. The leaves were washed, macerated in a Waring Blendor with distilled water and dry ice, and steam-distilled; the extracted oils were stored at $-10^{\circ} \mathrm{C}$ until analysis.

For rind-oil analysis, three to five healthy, mature fruits from Eureka and Lisbon lemon parents, and each of 29 progeny hybrids of Eureka $\times$ Lisbon lemon, Indian lime, and Yemen and Spadifora citron were peeled and the flavedo portion macerated and steamdistilled as described above. The extracted oils were stored at $-10^{\circ} \mathrm{C}$. Harvests were made in April of 1968 and 1969 , although in a few cases fruit was available for only one of these years. 
The analyses were carried out with a Varian Gas chromatograph, Model 1520. Injection sample size for leaf and rind oils was $10 \mu 1$. Two matched $305 \times$ $0.64 \mathrm{~cm}$ stainless steel columns were used. The liquid phase consisted of 20 per cent LAC 446 (diethyl glycol adipate with penta erythritol) on 60 - to 80-mesh Chromosorb W. Injector and detector temperatures were $210^{\circ} \mathrm{C}$ and the column temperature was non-linearly programmed from 50 to $180^{\circ} \mathrm{C}$ in a 2.5-hour run.

Identification of individual peaks was performed as described by Scora and Malik (1970). Areas under the peaks were computed by a Varian Digital Integrator, Model 475, then converted to percentages by weight (Appendices $A$ and $B$ ) and analyzed for taxa correlations.

For statistical computation, the percentage values of leaf and rind-oil components were rendered into averages; a three-factor analysis was conducted of the correlations among taxa and the purpose of providing simplified descriptions of relationships among taxa. The original data in per cent by weight were transformed into $\log _{10}$ to emphasize the smaller peaks. Correlations between taxa were calculated with peaks considered as observations. The factor analysis used was a principal component solution with an orthogonal rotation of the factor matrix. For rind oil, three factors account for 91 per cent of the variance; for leaf oil, three factors account for 92 per cent of the variance (Harman, 1960; Sokal and Sneath, 1963).

Statistical analysis of the leaf and rind-oil data was conducted using program BMDO3M of Factor Analysis in the computer center at the University of California, Riverside (Dipon, 1967).

Presence or absence of anthocyanin pigment was studied by observing the color of young flower buds, leaves, and stems of each plant. White flower buds and green young flush indicate the absence of anthocyanin, whereas any shade of brownish-red coloration in these plant parts indicates its presence. Presence of a joint between leaf petiole and leaf lamina was determined by visual observation on 100 randomly selected leaves of each plant. Plants with over 70 per cent leaves without leaf articulation were considered nonarticulated. The level of 70 per cent was used because of a distinct break in the distribution at that level.

Four 9-inch stem cuttings, one each from the four sides of each tree, were collected for observation of preformed root primordia. After removing the bark, root primordia were detected by viewing the stem pieces under a dissecting microscope at a magnification of $30 \times$ (Carpenter, 1961).

Ten mature leaves of each plant were selected randomly and very carefully run through a photocopier after reducing the leaf midrib and petiole to the same thickness as the leaf lamina by carefully shaving with a razor blade. All measurements were made on the resulting photoprints. Leaf blade length from apex to the point of articulation with the petiole and maximum blade width were determined. Length/width ratios were calculated for each leaf, and the mean ratio of 10 leaves for each plant was calculated.

Because flowering was scarce and erratic, flowers were collected when available. Twenty to 100 flowers were examined from each plant. Pistils were scored in three classes: (1) fully developed, (2) small, and (3) absent. Percentages of flowers with fully developed pistils were calculated. For determination of pollen viability, six recently opened flowers or mature buds of each flowering plant were collected and placed in covered petri dishes for 24 hours to allow the anthers to dehisce. Anthers of each flower were put two or three times in one or two drops of 0.5 per cent aceto-carmine stain on a microslide. Counts of stained and un- 
stained pollen grains were made at each of the three places in each of six slides made from six flowers. From these data, percentages of stainable pollen were calculated for each plant.

Presence of fruit was recorded for each plant, and the available fruit was used in other studies as required. Measurements were made mostly on five fruits per tree, except for a few cases where five fruits were not available. Measurements were made on weight, shape, style persistency, surface texture and color, peel thickness, number and size of oil glands, separation of segments, pulp color and texture, juice vesicles, juice amount, juice acidity, number of seeds, seed length and color, inner seed coat color, and polyembryony.

Two sets of all measurements were made: one in March-April, 1968, and the other in March-April, 1969. In a few cases, fruit was available only at one sampling.

For cytological studies, 15 to 20 young flower buds, 2 to $4 \mathrm{~mm}$ in diameter, were collected from those plants which had detectable amounts of stainable pollen. Buds were collected directly into freshly prepared 1:3 acetic-alcohol solution. Before placing the buds into the solution, petals were removed from larger buds, and the apices of very small buds were opened with forceps. Material was collected between 9 and 11 a.m., with temperatures ranging from 26 to $32^{\circ} \mathrm{C}$. After 24 hours of fixation, buds were washed three times in 70 per cent ethyl alcohol and then stored in the same fluid. Washing was repeated on two successive days to remove the acetic acid completely. Finally, the vials were stored at $4^{\circ} \mathrm{C}$. The material stored in this way remained in good condition for several months (Khush and Stebbins, 1961).

For slide preparation, four to five buds of varying size from each plant were removed from the storing fluid, washed in distilled water, hydrolyzed in $1 N \mathrm{HCl}$ for 5 to 6 minutes at room temperature, washed in running tap water for about 30 minutes and washed two to three times in distilled water in which it was stored during slide preparation. One or two anthers were smeared in one or two drops of 1 per cent Lacto-Propiono-Orcein stain (Haskell and Wills, 1968). Cover slips were temporarily sealed with dentist's sticky wax. Five to seven slides of each plant were stored at $4^{\circ} \mathrm{C}$ for about 24 hours before being studied. All the slides were analyzed at a magnification of $430 \times$ to $970 \times$. About 35 to 100 countable dividing pollen mother cells were studied in each plant. Percentages of pollen mother cells with abnormal meiotic behavior and percentages of abnormal sporads were calculated for each plant.

\section{RESULTS}

\section{Anthocyanin}

Of the 57 plants which flowered, 13 had white and 44 had dark, brown-red flower buds. Assuming that the presence of anthocyanin (brown-red color) is determined by a single dominant gene and that Citrus limon is heterozygous for this gene, a segregation ratio of three plants with anthocyanin to one without would be expected. The deviation from $3: 1$ is not statistically significant at the 1 per cent level. The flower buds of Eureka lemon, Lisbon lemon, and Yemen citron are colored, while Indian lime and Spadifora citron have white flower buds.

Out of 100 plants, 19 had green young leaves and 81 had various shades of brown-red color. The deviation from an expected $3: 1$ ratio is not significant at the 5 per cent level. The number of hybrids with varying color shades is given in table 1 . The young leaves of Eureka lemon and Yemen citron are 
dark brown-red; those of Lisbon lemon are light brown-red; and those of Indian lime and Spadifora citron are green.

TABLE I

YOUNG LEAF AND STEM COLOR OF 100 LEMON HYBRIDS

\begin{tabular}{l|c|c|c}
\hline \multirow{2}{*}{ Leaf color } & \multicolumn{3}{|c}{$\begin{array}{c}\text { Number of plants with } \\
\text { following stem color : }\end{array}$} \\
\cline { 2 - 4 } & Brown-red & Green & Total \\
\hline $\begin{array}{l}\text { Dark brown.red .... } \\
\text { Medium dark } \\
\text { brown-red ....... }\end{array}$ & 39 & 0 & 39 \\
Medium brown-red ... & 0 & 11 & 21 \\
Light brown-red .... & 0 & 11 & 11 \\
Green............ & 0 & 10 & 10 \\
\hline Total......... & 49 & 51 & 100 \\
\hline
\end{tabular}

Of 100 plants rated, 49 had brownred and 51 had green young stems. The segregation ratio in this case does not agree with the segregations of flower buds and young leaf color. It does not differ significantly from a 1:1 segregation ratio. An alternate possibility is that the color in the young stems is controlled by two gene pairs, and that both dominant genes are required for color development. An $\mathrm{F}_{2}$ segregation ratio of $9: 7$ would then be expected. The deviation from a 9:7 ratio is not significant at the 5 per cent level. Young stems of Eureka lemon and Yemen citron have color, while Lisbon lemon, Indian lime, and Spadifora citron have green young stems.

It was also obvious from these studies that plants with any shade of colored leaves also had color in their flowers, and green-leaved plants had only white flowers (table 1).

\section{Leaf and stem}

Plants with over 70 per cent leaves without leaf articulation were considered nonarticulated. On this basis, 93 plants were rated articulated and seven plants nonarticulated in the progenies studied. This shows a close approximation to a ratio of 15 articulated to 1 nonarticulated, the assumption being that only the homozygous recessive individ- uals are nonarticulated. The probability of the chi-square for goodness of fit was 75 per cent. Eureka lemon, Lisbon lemon, and Indian lime have articulated leaves, while Yemen citron and Spadifora citron have no leaf articulation.

Seventy-eight out of 100 plants of these progenies had no preformed root initials, while 22 plants had from one to four per sample examined. The observed ratio does not differ significantly from a $3: 1$ ratio at the 5 per cent level. Eureka lemon, Lisbon lemon, and Indian lime do not have preformed root initials, but Yemen eitron and Spadifora citron do.

Figure 1 shows (1) the mean leaf length/width ratios for Eureka lemon, Lisbon lemon, Indian lime, Yemen citron, and Spadifora citron, and (2) the frequency distribution of this ratio for the progeny.

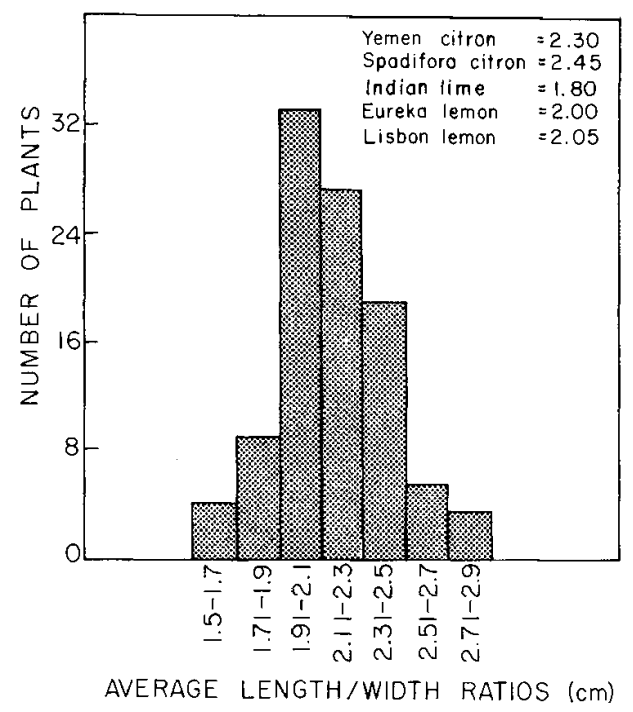

Fig. 1. Average length/width ratios of leaves of lemon hybrids. Average ratios of the parents and potential ancestors are also indicated.

\section{Flower and fruit}

Figure 2 shows the frequency distribution of the percentages of pistillate flowers in this progeny, and the values for Eureka and Lisbon lemons 
(parents), Indian lime, and Yemen and Spadifora citrons.

In 35 of the 57 flowering plants no stainable pollen was found. The distribution of percentages of stainable pollen of the remaining 22 plants is shown in figure 3 . For comparison, the values for stainable pollen of Eureka and Lisbon lemons, C. aurantifolia (Indian lime), and $C$. medica (Yemen and Spadifora citrons) are also given.

Fruit was available on only 29 out of 100 plants of this progeny. Twelve plants produced fruits once in two years of study, with a range of only one to five fruits.

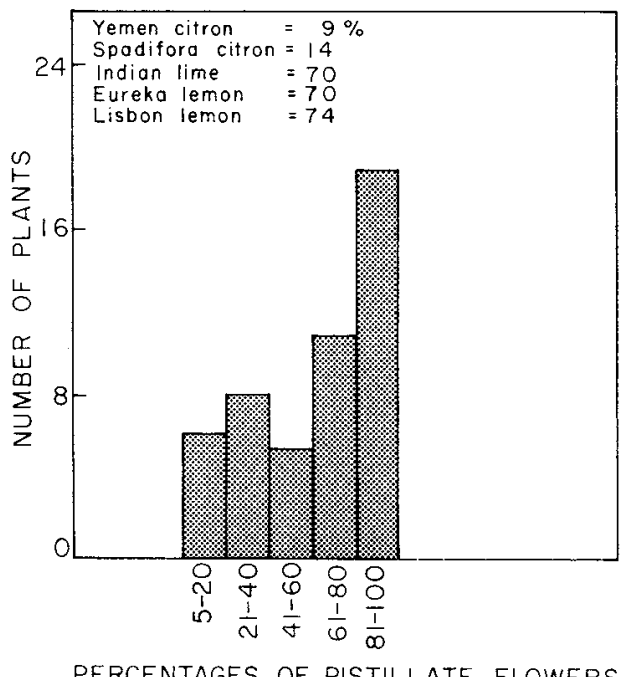

Fig. 2. Percentages of pistillate flowers of lemon hybrids. Average percentages of the parents and potential ancestors are also indicated.

The frequency distribution of the average fruit weight grouped by classes of $20 \mathrm{~g}$ is shown in figure 4 . Average weights of Eureka lemon, Lisbon lemon, Indian lime, Yemen citron, and Spadifora citron are also shown.

Figure 5 shows fruit length plotted against diameter. Fruit measurements of Eureka lemon, Lisbon lemon, Indian lime, Yemen citron, and Spadifora citron are also shown. Six plants are similar to Indian lime, 12 are like the

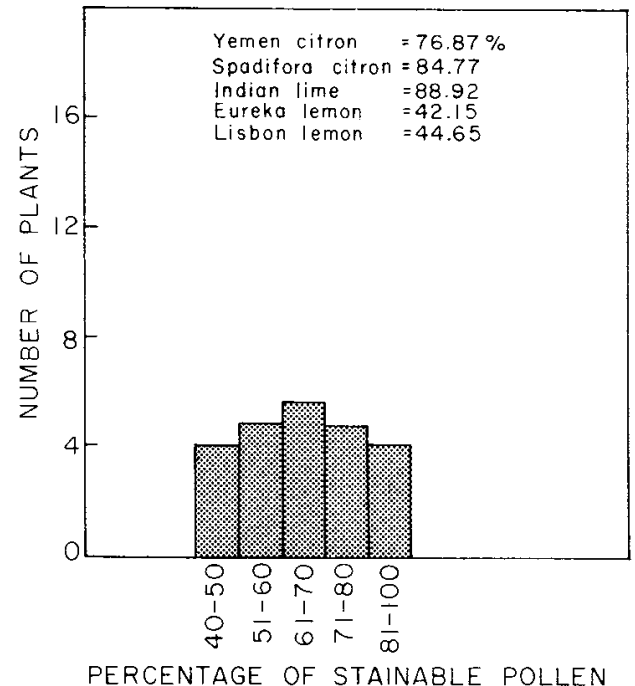

Fig. 3. Percentages of stainable pollen of lemon hybrids. Average percentages for the parents and potential ancestors are also indicated.

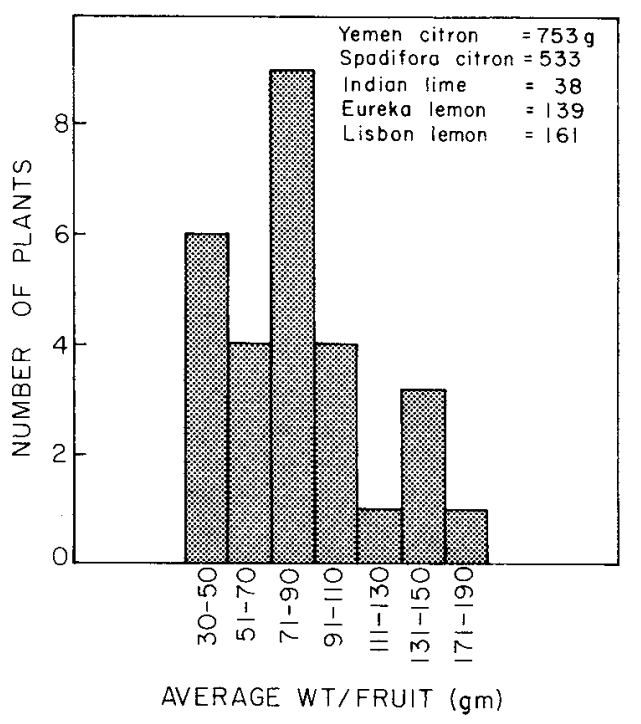

Fig. 4. Arerage fruit weight of lemon hybrids. Average weights for the parents and potential ancestors are also indicated.

lemon, 10 are in between the lime and the lemon, and one is between the lemon and the citron.

Fruit shape varied from globose to pyriform, including ellipsoid, oblique, ovoid and obovoid. Most of the fruiting progeny (10) were ellipsoid with the 


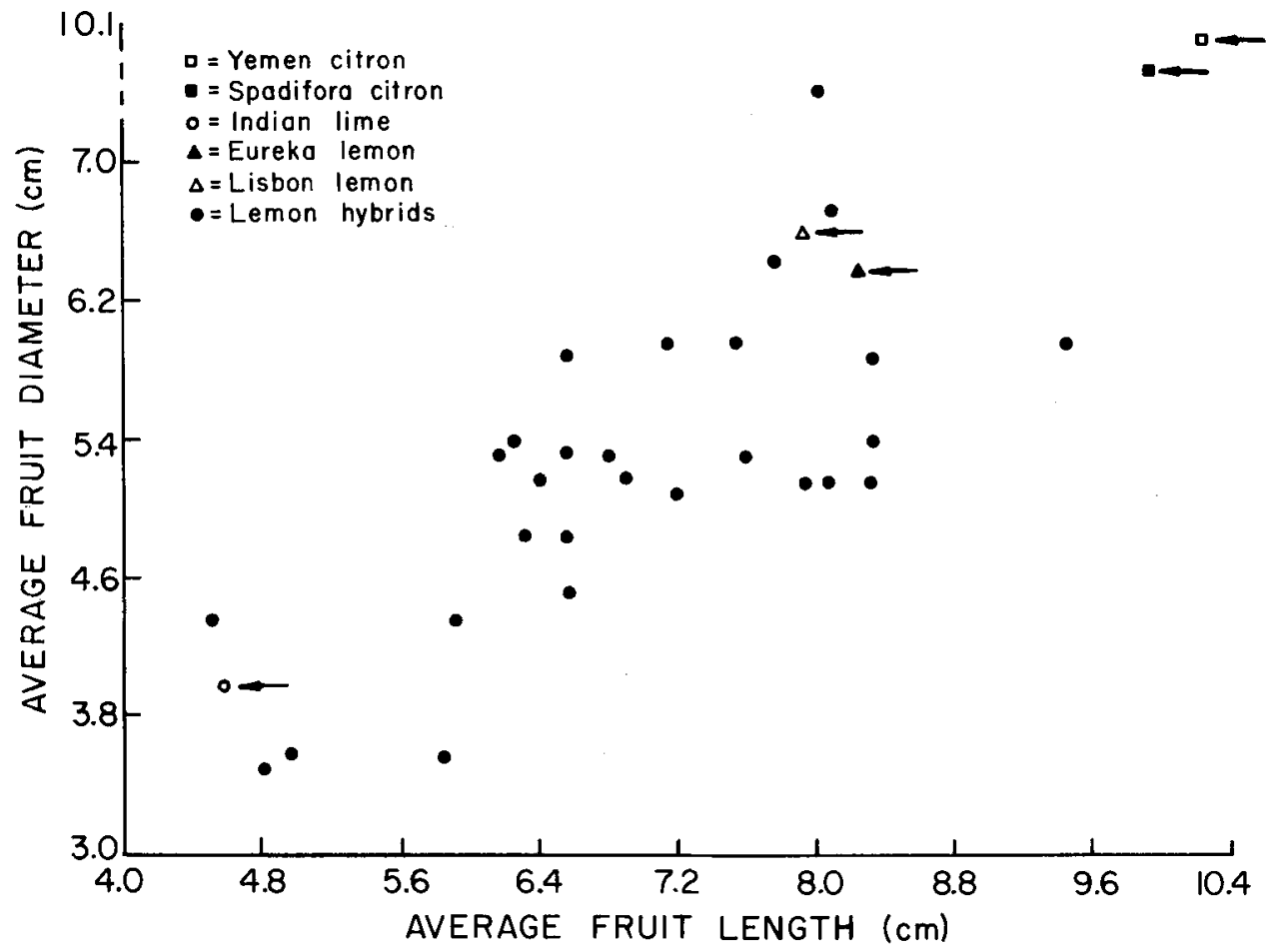

Fig. 5. Plant distribution according to average fruit length and diameter of lemon hybrids. Average values for the parents and potential ancestors are also indicated.

remainder distributed in the other classes. The lemon clones vary from ellipsoid to pyriform, and Indian lime from ellipsoid to collared, Yemen and Spadifora citrons are generally ellipsoid.

Seven plants had fruit with rounded apices, and 22 had abruptly pointed apices or protruding nipples. Five out of 29 plants had fruit with persistent styles. Eureka and Lisbon lemon, Indian lime, Yemen citron, and Spadifora citron had abruptly pointed apices. The citron clones also had persistent styles.

Of the 29 fruiting plants, 22 had smooth or nearly smooth rind surfaces, six were coarse-to-rough with one pebbled. The lemons and Indian limes are smooth or nearly smooth; the citrons are pebbled-to-coarse.

Fruit-rind color varied from greenyellow to light orange-yellow color.
None of the fruits approached full orange color or developed any red or pink. The lemon parents were lemonyellow color, while Indian lime had green-yellow color. Both Yemen citron and Spadifora citron had fruit of bright yellow color.

Pulp color ranged from yellow to white, including four green-yellow, three white, and $\mathbf{1 6}$ yellow. The flesh color of Eureka lemon and Lisbon lemon was light yellow to yellow; Indian lime was light green-yellow; and Yemen citron and Spadifora citron were white.

Juice of Eureka lemon, Lisbon lemon, Indian lime, and Yemon citron had acid juice, while Spadifora citron had nonacid juice.

Four plants had seedless fruits; the other 25 had seeds in varying frequencies: sixteen had 1-to-4, three had 5-to8 , and six averaged less than 1 seed per 
fruit. Eureka lemon had 13 seeds per fruit, Indian lime three, and Yemen citron and Spadifora citron 145 and 142, respectively. Seed length varied from 5-to-15 mm, with 12 plants having an average length of 9-to-11 mm. Three had seeds are large as citron $(10-12 \mathrm{~mm})$, four as small as Indian lime $(7 \mathrm{~mm})$.

Thirteen plants had brown, 10 had light brown, and two had very light brown seed coats. Eureka lemon, Lisbon lemon, and Indian lime had light brown inner seed coat; Yemen citron's was brown; and Spadifora citron's was white. Sixteen plants had dark brown, seven had brown, and two had light brown color at the chalaza-end of their seeds. Eureka lemon, Lisbon lemon, and Indian lime had seeds with brown chalaza ends; Yemen citron had dark brown chalaza ends; Spadifora citron's were white-yellow.

The available number of seeds per plant was too small to make reliable determinations of monoembryony. However, seven of the 25 plants with

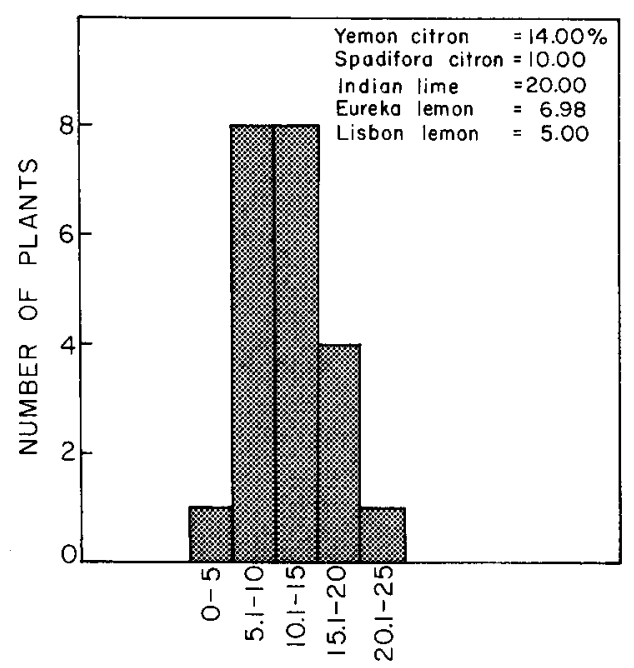

PERCENTAGE OF POLLEN MOTHER CELLS WITH ABNORMAL MEIOTIC BEHAVIOR

Fig. 6. Percentages of pollen mother cells with abnormal meiotic behavior in lemon hybrids. Average percentages of the parents and potential ancestors are also indicated.

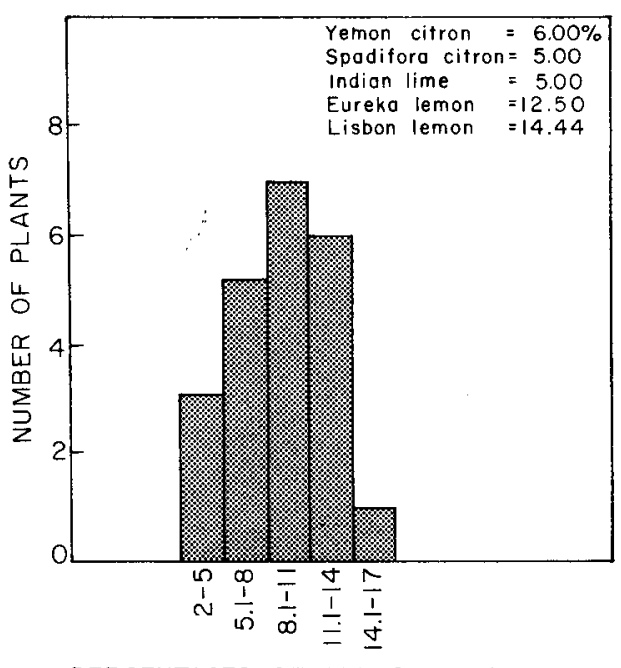

PERCENTAGES OF ABNORMAL SPORADS

Fig. 7. Lemon hybrids according to percentage values of their abnormal sporads. Average percentages for the parents and potential ancestors are also indicated.

seeds had polyembryonic seeds. Eureka lemon, Lisbon lemon, and Indian lime are polyembryonic, while both citrons are monoembryonic.

The frequency distribution of the percentages of pollen mother cells with abnormal meiotic behavior in progeny, the lemon parents, Indian lime, Yemen citron, and Spadifora citron are given in figure 6. Meiosis was not studied in detail due to poor stainability. However, all abnormal pollen mother cells had at least several univalents at first anaphase. Many of the univalents lagged at first anaphase or underwent precocious division. Second anaphase was greatly disrupted with numerous micronuclei being formed. The distribution of the percentages of abnormal sporads is shown in figure 7 . The values for Eureka lemon, Lisbon lemon, Indian lime, Yemen citron, and Spadifora citron are also given.

\section{Leaf oils}

Figure 8 , observed as a plane in the first and second dimensions $\left(F_{1}, F_{2}\right)$ shows that the most obvious concentra- 


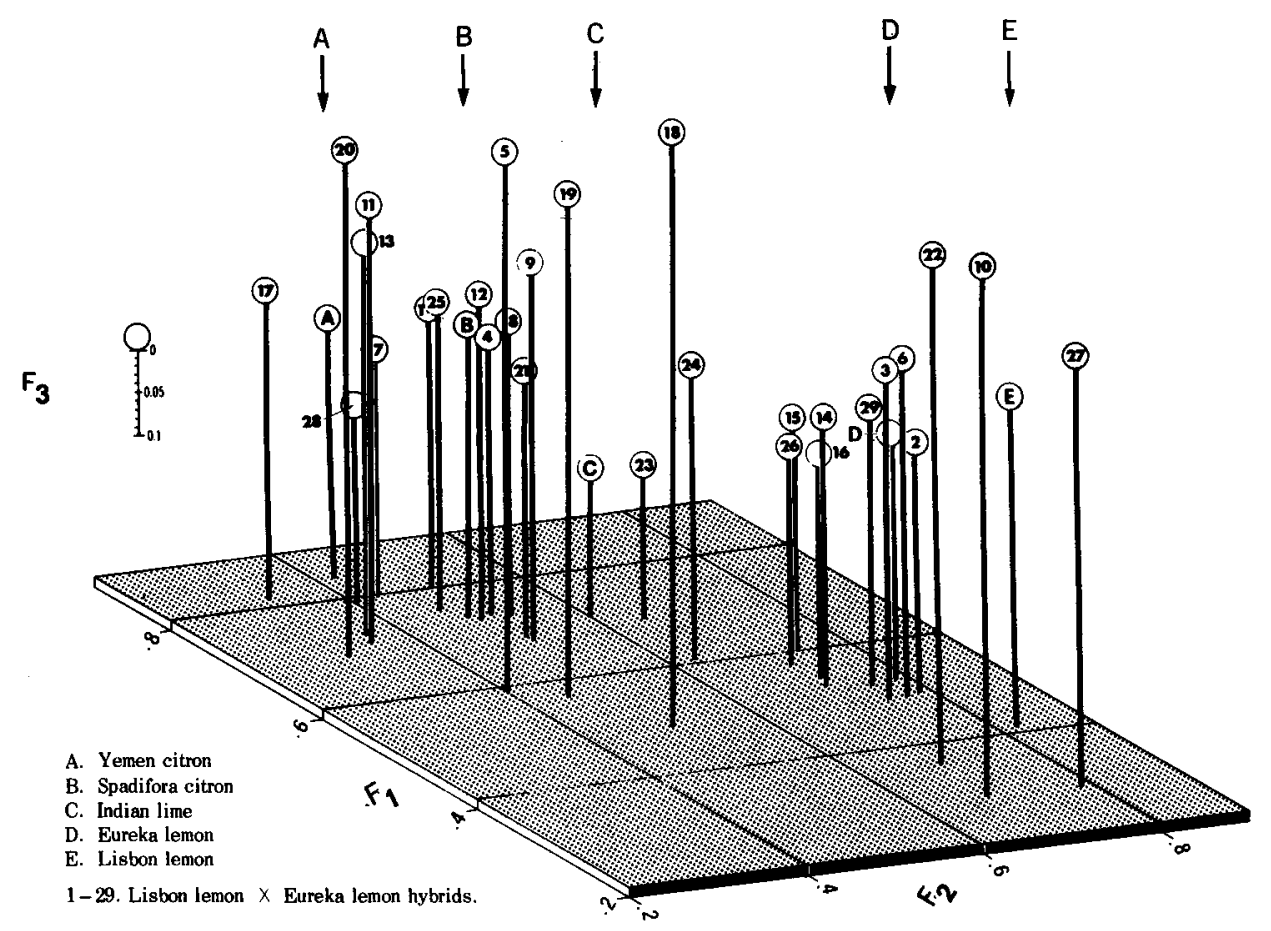

Diagram of three-factor analysis of rind oil components of lemon hybrids, their parents and possible ancestral types.

Fig. 8. The relationship of 40 Lisbon lemon $\times$ Eureka lemon hybrids to each other and to their parents and possible ancestral types, based upon a three dimensional presentation ( $F 1$, F2, F3) of their leaf oil components.

tion of hybrids clusters around and between the parental lemon types ( $\mathbf{E}$ and $\mathrm{D}$ arrows). A few hybrids are loosely arranged around the possible ancestral types (A, B, C arrows). Another loose elustering of hybrids occurs at the right side of the plane. Few hybrids are dispersed between these two clusters.

In the third dimension, represented as height factor, there is a relatively homogeneous clustering of hybrids on the right, with hybrid 39 the most obvious deviant. This deviation is possibly due to a lack of d-limonene and a doubling of $\beta$-myrcene as compared to the parental lemons. Most of the other essential oil components of hybrid 39, because of the small amount of d-limonene, are present in larger percentages than in the parental Eureka and Lisbon lemons or in Indian lime, Yemen, and Spadifora citron. The difference is most pronounced in the case of neral, citronellol, and geranial. Arrangement of the hybrids around the possible ancestral types (A, B, C) shows much heterogeneity. Hybrids 1, 18 , and 30 deviate considerably because of their negative values. Particularly surprising is the difference between Spadifora and Yemen citron; the former shows positive and the latter negative monoterpene values. This difference is due to a drastic reduction of d-limonene and an approximate doubling of the amounts of neral, citronellol, and geranial in Spadifora, as compared to Yemen citron.

Hybrids 2 and 9 have positive values 


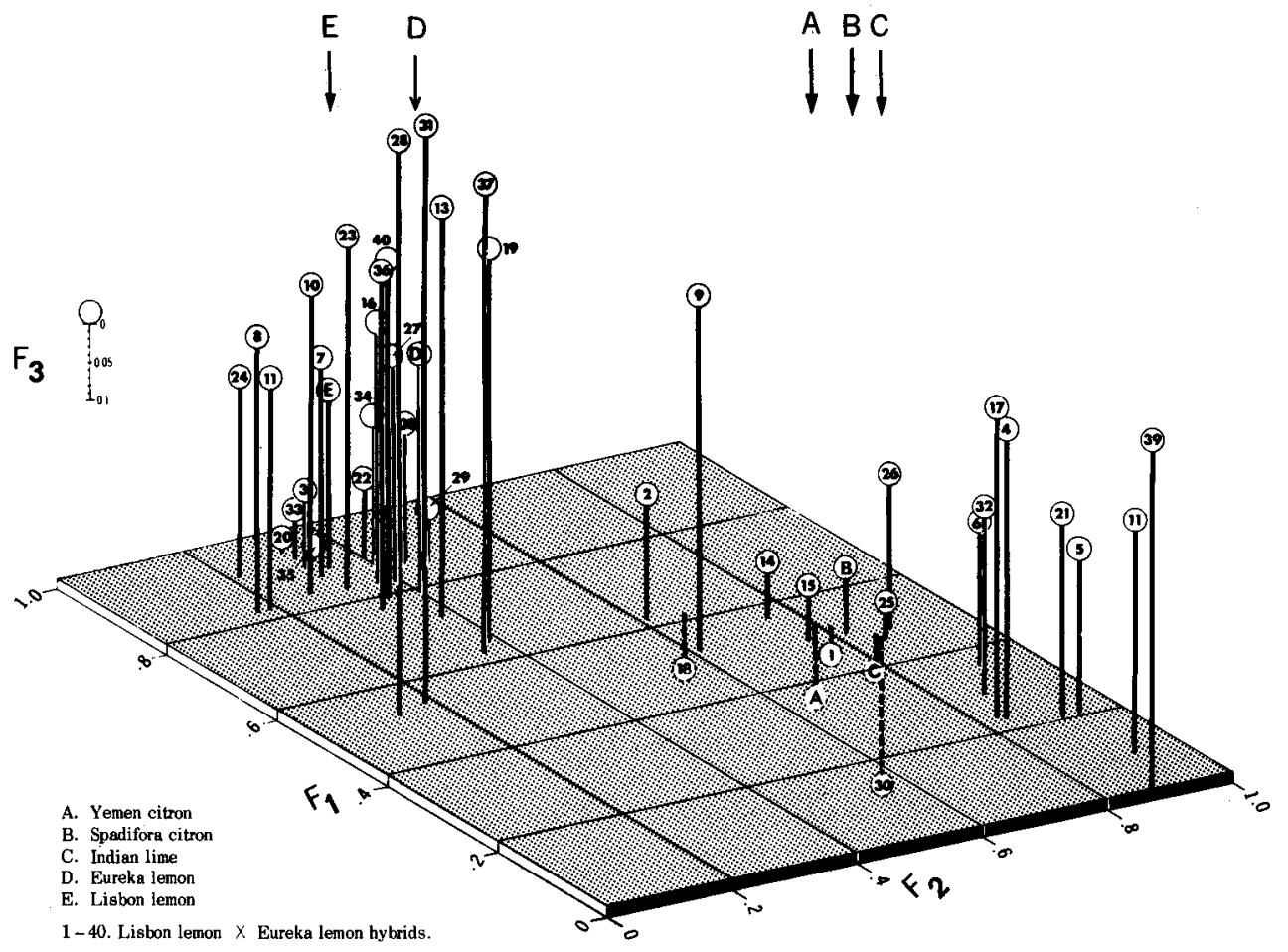

Diagram of three-factor analysis of leaf oil components of lemon hybrids, their porents and possible ancestral types.

Fig. 9. The relationship of 29 Lisbon lemon $\times$ Eureka lemon hybrids to each other and to their parents and possible ancestral types, based upon a three dimensional presentation ( $F 1$, $\mathrm{F} 2, \mathrm{~F} 3$ ) of their rind oil components.

in contrast to hybrid 18 . The position of hybrid 9 is due to the fact that $\beta$ pinene, $\beta$-myrcene, neral, citronellol, and geranial are present in much lesser quantities, and sabinene and linalool are present in high amounts. The negative values of hybrid 18 are due to the large quantities of sabiene, d-limonene, $\mathrm{p}$-cymene, linalool, and $\beta$-elemene and the small amounts of neral, citronellol, and geranial compared to the parental lemons.

The large grouping between the parental lemon types ( $\mathrm{E}$ and $\mathrm{D}$ ) also indicates a wide heterogeneous arrangement in the third dimension, of which hybrids 28 and 31 are the most deviant due to trace amount of d-limonene only. Hybrids 20 to 35 deviate in other directions, due to the larger amount of d-limonene, as compared to the lemons and lesser amounts of neral, citronellol, and geranial.

\section{Rind oils}

Figure 9 presents the three-factor analysis of rind oils obtained from 29 hybrids and their parental and possible ancestral types. In the two-dimensional plane, a clustering of hybrids is again observed around the immediate parental types (D and E), namely Eureka and Lisbon lemons. A similar homogeneity also occurs in the third dimension, with only hybrids 22 and 10 deviating. Another grouping centers primarily on Yemen and Spadifora citrons $(\mathrm{A}, \mathrm{B})$. In the third dimension, this group is quite homogeneous, with the exceptions of hybrids $5,11,13$, and 
20. The possibly ancestral Indian lime (C) tends to be closer to Spadifora and Yemen citrons than to the lemons in its rind oil components. This closeness is also shown in the leaf oil components. A highly heterogeneous, loose clustering occurs around the lime with hybrids 19 and 18 the most obvious deviants. Hybrid 18 deviates from the lime, having much lower quantities of $\beta$-pinene and neral, and more of $d$ limonene and $\gamma$-terpinene and $p$ cymene than the lime. Hybrid 23 is the most similar to the Indian lime, except for its content of neral, which is present in trace amounts only.

\section{DISCUSSION}

The segregation ratios of anthocyanin (color) in this progeny indicate that $C$. limon is probably heterozygous for a single dominant gene which produces brown-red color in the flower buds and young leaves. These results agree with the findings of Toxopeus (1962) for 'Meyer' lemon (C. limon) seedlings. The results for the color in the young stems of lemon hybrids do not agree with the segregation ratios found in flower buds and young leaf color.

Different shades of brown-red were found in the young leaves of this progeny. The plants with dark, brown-red young leaves had brown-red colored young stems. Green young stems were present in all the plants which had leaves of medium brown-red, light brown-red, or green color. The expression of the genes controlling color may be affected by modifying genes, by different genetic background of the hybrids, or there may be different genes controlling color in the young stems.

As no definite brown-red was observed in the young stems of one of the parents (Lisbon lemon), the resulting ratio of one brown-red colored to one green-stemmed plant may be due to crossing plants which were heterozygous with plants homozygous recessive for the gene which gives brown-red in the young stems.

Complementary effects of two pairs of alleles, where both dominant genes $A$ and $B$ are required for the appearance of color in the young stems, could also explain the difference in ratios between leaves and stems. Possibly gene $A$, which controls the color in the flower buds and young leaves, also controls the color in young stems, along with another gene $B$, to give the observed ratios.

Few of this progeny produced flowers and fruit, and the percentages of pistillate flowers and pollen stainability deviated greatly from the parent lemon types. The high percentage of flowerless and fruitless plants and the deviation of the progeny from the immediate parents in percentages of pistillate flowers and pollen stainability indicate that there were heterozygous genetic factors in a balanced stage in the parental lemon types.

The variation in morphological characteristics of the available fruit of plants in this progeny, such as weight, shape, surface texture, rind thickness, seediness, and color of inner seed coat, is additional evidence that the lemon is very heterozygous.

Characters such as large petiole wings, presence of sweet taste, and orange-to-red pigment in the fruit which are associated with some of the Citrus taxa other than the lime-lemoncitron group, were not found in the lemon progeny, indicating that these gene sources may not be involved in the lemon phylogeny.

The variation in the percentage of pollen mother cells with abnormal meiotic behavior again indicates segregation of factors controlling fertility. Although abnormal meiotic behavior is 
significantly correlated with the presence of abnormal sporads, some plants with low meiotic abnormality had a high percentage of abnormal sporads, indicating that additional factors are involved in their production. The number of abnormal sporads was highly correlated with the amount of unstainable pollen grains in this progeny, indicating little if any failure of microspores.

Colored and white flower buds, colored and green young growth flush, presence and absence of preformed root primordia in the stems, articulated and nonarticulated leaves, great range in fruit size and shape, and presence of fruits with and without persistent style in the progeny suggest that more than one gene source is involved in the genetic make-up of the lemon. The wide differences exhibited in many specific characteristics indicate that more than one taxon has contributed to the gene constitution of the lemon.

Preformed root primordia (Carpenter, 1961), nonarticulated leaves, and fruit with persistent style (Swingle, 1943) are characteristic features of $C$. medica. The presence of these characteristies in the lemon progeny strongly suggests that the citron is involved in the lemon parentage. White flower buds and green new growth flush in the lemon hybrids was first considered to indicate the involvement of a parent other than the citron; but color in the flower buds and new growth was considered to be from the citron. The present studies clearly show that Spadifora and some other citron varieties have white flower buds and green young growth flush. The gene causing the presence of flower bud coloration and new growth color may therefore be from some source other than the citron. However, the citron cultivars which had white flower buds and green young growth flush also had only nonacid fruit. In the lemon progeny, all hybrids had acid fruits regardless of flower and new growth color. This evidence indicates that the citron which might have been involved in the parentage of lemon probably had colored flower buds, colored young growth flush, and acid fruit.

The presence of individuals in this progeny with small fruit having smooth, thin peel indicates the presence of another lemon parent with these characteristics. Citrus aurantifolia which has white flower buds, green young growth flush, and small acid fruit with smooth, thin peel (Swingle, 1943) might be one of the parents other than citron.

Some of the fruits of this hybrid progeny resemble, to some extent, 'Rough' lemon (C. jambhiri Lush.) in their rough and bumpy peel, fruit size and shape, and in semisolid to hollow fruit core. Some of them also showed some characteristics similar to those of C. limon. These observations again indicate the probable involvement of another genetic source in the genotypic makeup of $C$. limon (L.) Burm. f.

The leaf length/width ratios of flowers, percentage of stainable pollen, and some fruit characteristics resemble neither their parental types nor their assumed ancestral types.

The analysis of leaf oils showed a pattern similar to that shown by the morphological characteristics. As expected, a large majority of the hybrids are similar to the parental lemon varieties in morphology and some approach Indian lime and the citron varieties (fig. 10). However, several are clearly separated from the parental varieties and the assumed ancestral types (citron and lime). Available leaf oil analyses of $C$. sinensis (L.) Osbeck, $C$. reticulata Blanco, C. aurantium L., and C. grandis (L.) Osbeck were compared with the leaf oil analysis of these variant hybrids. The variants were clearly different from all taxa previously analyzed. Leaf oils of C. hystrix D.C. and C. macroptera Montr. were subse- 


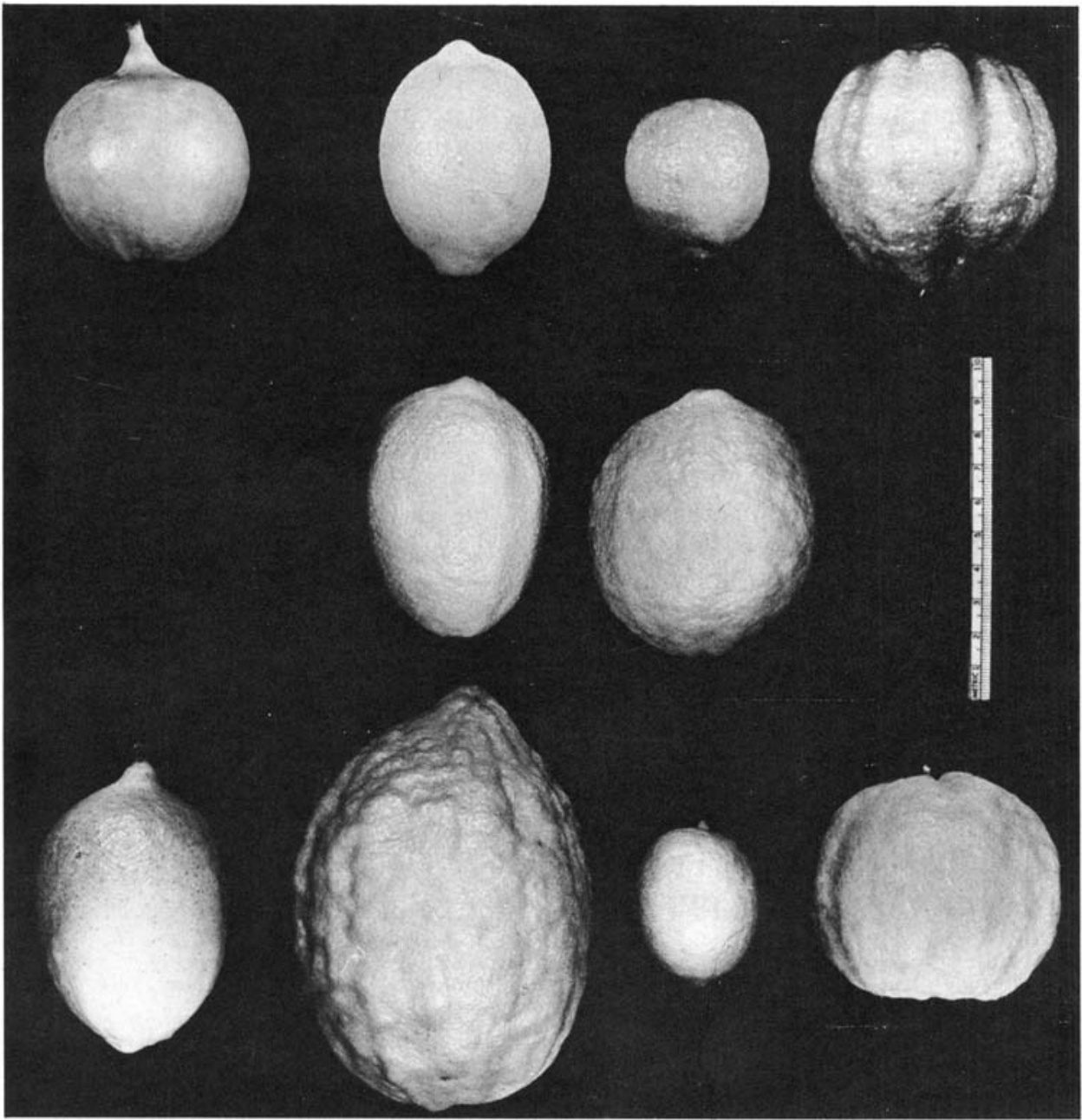

Fig. 10. Fruit shapes of parents, hybrids, and possible ancestral types. Left column, top to bottom; Etrog citron, Spadifora citron, Mexican lime, Rough lemon. Middle column, range of parent lemon fruit shapes. Right column, selected fruit shapes of hybrids, illustrating range of shape and rind texture.

quently analyzed and found to be clearly different from the hybrids. Available evidence from leaf oils, therefore, also indicates the presence of genes in the lemon that are from some taxa other than those tested to date.

Just as the flower is less subject to change than the leaves and therefore better suited for phylogenetic investigations, we suggest citrus leaves are more biochemically conservative than the fruit. The fruit has probably un- dergone more selection pressures than the leaves because of its use by man and animal, and therefore we can expect different essential oil evolution in leaf and rind. In the fruit rind oil analysis, we see again a cluster around the parents and an almost equally large cluster with the lime and the citrons, but very few hybrids are between these two large groups. Thus, the rind oil analysis offers little indication of an additional genetic source. 
Tanaka (1969b) proposed that, while still in the tropics, the citrus fruit must have transformed into lime form (section Limonellus) and migrated northward from its place of ancestry, the Malayan Archipelago, differentiating in the cooler climate of the Himalayan regions into a citron-lemon complex (section Citrophorum). Both leaf and rind oil analyses give very surprisingly similar patterns for the lime and the citron. Most of the morphological characteristics do not agree with Tanaka's concept. However, both morphological and essential oil analyses show some individuals differing from both the parental and the assumed ancestral types, which suggests the possibility of the involvement of another genetic source in lemon ancestry.

A three-factor analysis of the leaf and rind oil components of the lemon hybrids, the parental lemon types, and of the possible ancestors showed a large clustering around and in between the immediate parents, another grouping around the possible ancestral types, and a few other plants separated from both groups, again suggesting that the lemon is heterozygous.

Geographically, the assumed places of origin of the citron and the lime overlap where the lemon is found, but these areas are in part also those where other citrus types, such as Rough Lemon and sour orange, occur. It is probable, therefore, that other citrus types which might have contributed to the genetic make-up of the lemon also inhabit those areas.

One may conclude from the chemical and morphological data available that the lemon is probably neither a distinct, valid species, nor is it clearly a first generation hybrid between the citron and the lime. Citron probably is one of its parents, but an unknown genetic source outside of the citronlime group also appears to have contributed to its origin.

\section{LITERATURE CITED}

BhatTacharya, S. C., and S. DUTta

1956. Classification of citrus fruits of Assam. Sci. Monogr. No. 20, ICRA, New Delhi, India. BONAVIA, E.

1888. The cultivated oranges and lemons, etc. of India and Ceylon. London: W. H. Allen and $\mathrm{Co}$.

Carpenter, J. B.

1961. Occurrence and inheritance of preformed root primordia in stems of citron (Citrus medica L.). Proc. Amer. Soc. Hort. Sci. 77:211-18.

De Candolle, Alphonse

1886. Origin of cultivated plants. 2nd ed. London : Kegan Paul.

Dipon, W. J. (ed.)

1967. Program BMDO3M of factor analysis. Biomedical Computer Program (2nd ed.). Berkeley and Los Angeles: Univ. California Press.

Gallesio, G.

1876. Orange culture. A treatise on the citrus family. (Translated from the French expressly for the Florida Agriculturist.) Tacksonville, Florida: H. Walton \& Co. 65 pp.

HARMAN, H. H.

1960. Modern factor analysis. Chicago: Univ. Chicago Press.

HASKELL, G., and A. B. WiLLS

1968. Primer of chromosome practice. Edinburgh and London: Oliver and Boyd.

HodGsON, R. W.

1955. Origin of citrus fruits grown in California. Calif. Citrogr. 49:118, 132-36.

1961. Taxonomy and nomenclature in citrus. Intern. Org. Citrus Virol. Proc. 2:1-7.

Kesterson, J. W., A. P. Pieringer, G. J. Edwards, and R. Hendrickson

1964. Application of gas-liquid chromatography to the citrus leaf oils for the identification of kinds of citrus. Proc. Amer. Soc. Hort. Sci. 83:199-203. 
Khush, G. S., and G. L. SteBbins

1961. Cytogenetics and evolutionary studies in Secale. I. Some new data on the ancestry of Secale cereale. Amer. Jour. Bot. 48:723-30.

Linnaeus, Card

1753. Species Plantarum. Vol. II. Holmiae (Stockholm), Impensis Laurentii Salvii [Printed for the Ray Society, London, in 1959.]

Lushington, A. W.

1910. The genus Citrus. Ind. For. 36:323-53.

Marcovitch, B. B.

1926. Classification of the genus Citrus. In: Landbouw, Buitenzorg 2(4):1-25.

MicheL, E. (ed.)

1816. Traité du Citronnier. Paris: Bertrand.

Pieringer, A. P., C. J. Edwards, and R. W. Wolford

1964. The identification of citrus species and varieties by instrumental analysis of citrus leaf oils. Proc. Amer. Soc. Hort. Sei. 84:204-12.

Risso, J. A.

1813. Essai sur l'histoire naturelle des oranges, bigaradiers, limettiers, cédratiers, limoniers ou citroniers, cultivés dans le Départment des Alpes Maritimes. Ann. Mus. Paris $20: 169-212$.

Scora, R. W., G. Duesch, and A. B. England

1969. Essential leaf oils in the Rutaceae. Amer. Jour. Bot. 56:1094-102.

SCORA, R. W., and M. N. MALIK

1970. Chemical characterization of cultivated plants as a tool in phylogeny. Taxon 215:228.

Sokal, R. R., and P. A. Sneath

1963. Principles of numerical taxonomy. San Francisco and Iondon: W. H. Freeman and Co. $359 \mathrm{pp}$.

SWINGLE, W. T.

1914. Citrus and related genera (p. 779-785). In L. H. Bailey, Standard Cyclopedia of Horticulture. New York: The Macmillan Co.

1943. The botany of citrus and its wild relatives of the orange family (p. 129-474). In H. J. Webber and L. D. Batchelor (eds.), The Citrus Industry, Vol. I. Berkeley and Los Angeles : Univ. California Press.

TANAKA, T.

1954. Complication of citrus nomenclature; species problem in eitrus. Hort. Inst. Tokyo Agr. Univ., Tech. Paper No. 10.

1969a. Taxonomic problem of citrus fruits in the Orient. Bull. Univ. Osaka Pref., Ser. B, 21: 133-38.

1969b. Misunderstanding with regards to citrus classification and nomenclature. Bull. Univ. Osaka Pref., Ser. B, 21:139-45.

ToLKowsKY, $\mathbf{S}$.

1938. Hesperides. A history of culture and use of citrus fruits. London: John Bale, Sons and Curnow, Ltd.

Toxopeus, $\mathrm{H}$.

1962. Notes on the genetics of a few leaf characters in the genus Citrus. Euphytica 11:19-25.

WebBer, H. J., W. Reuther, and H. W. LAWtoN

1967. History and development of the citrus industry. In W. Reuther, H. J. Webber, and L. D. Batchelor (eds.), The Citrus Industry, Vol. I (rev.), p. 1-39. Berkeley: Univ, California Press. 
APPEndix TABLe A

AVERAGE PERCENTAGES OF LEAF-OLL COMPONENTS IN LEMON HYBRIDS, THEIR PARENTS, AND POSSIBLE ANCESTRAL TYPES

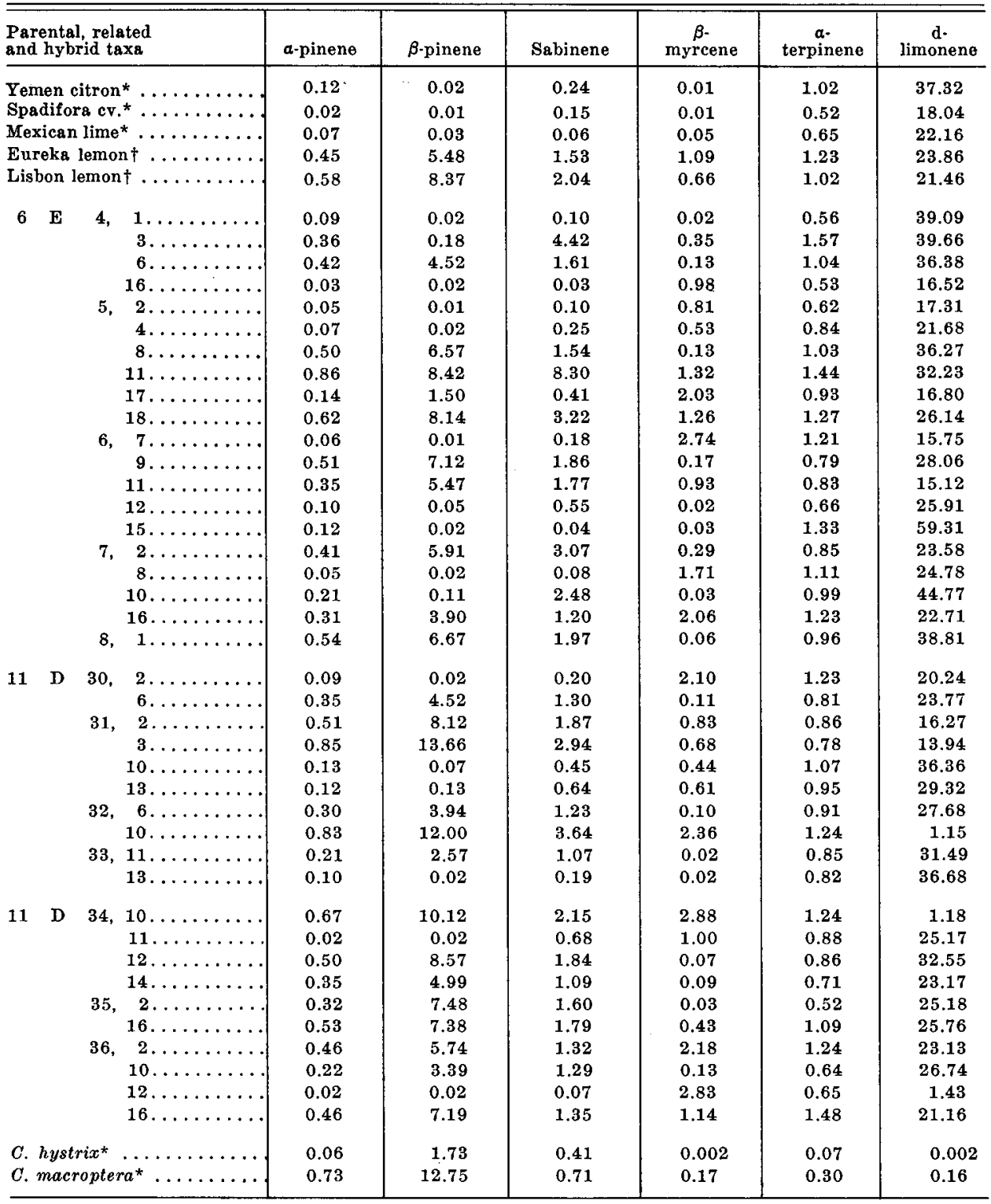

* Related taxa.

+ Parental taxa.

(All others are hybrid taxa.) 
TABLE A (Cont.)

AVERAGE PERCENTAGES OF LEAF-OIL COMPONENTS IN LEMON HYBRIDS, THEIR PARENTS, AND POSSIBLE ANCESTRAL TYPES

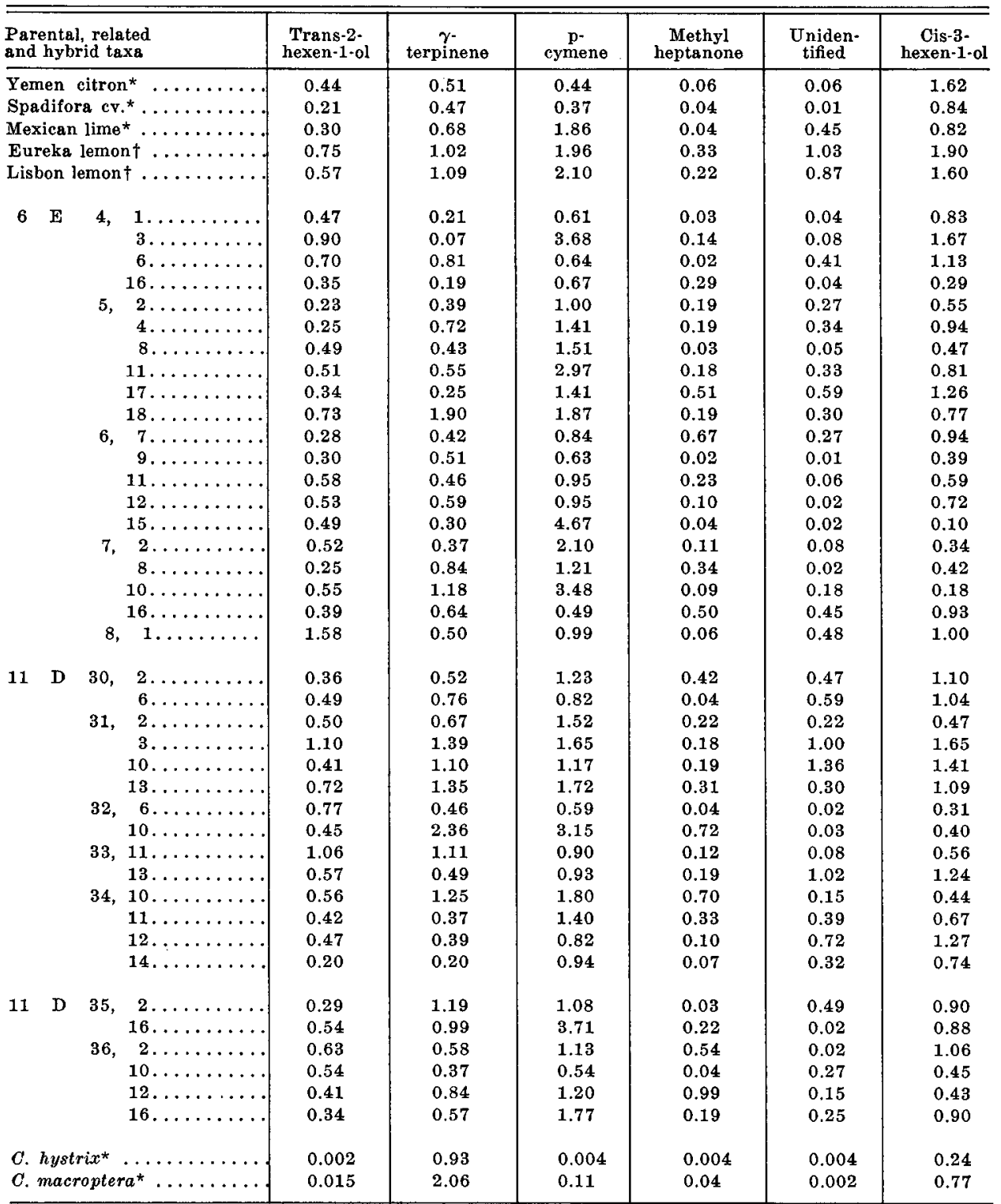

* Related taxa.

+ Parental taxa.

(All others are hybrid taxa.) 
TABLe A (Cont.)

AVERAGE PERCENTAGES OF LEAF-OIL COMPONENTS IN LEMON HYBRIDS, THEIR PARENTS, AND POSSIBLE ANCESTRAL TYPES

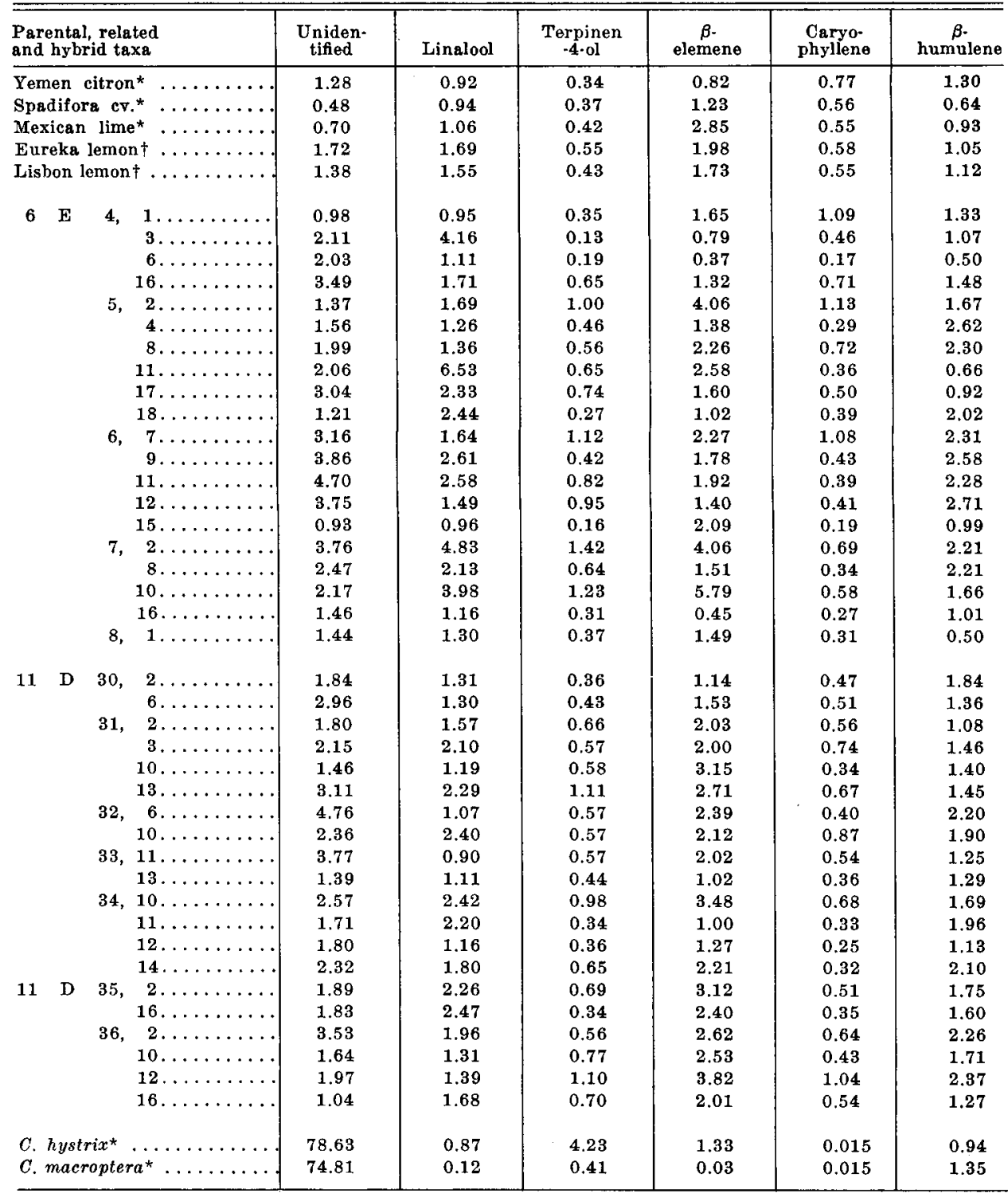

* Related taxa.

t Parental taxa.

All others are hybrid taxa. 
TABLE A (Cont.)

AVERAGE PERCENTAGES OF LEAF-OIL COMPONENTS IN LEMON HYBRIDS, THEIR PARENTS, AND POSSIBLE ANCESTRAL TYPES

\begin{tabular}{|c|c|c|c|c|c|}
\hline \multicolumn{2}{|c|}{$\begin{array}{l}\text { Parental, related } \\
\text { and hybrid taxa }\end{array}$} & $a$-terpineol & Neral & Citronellol & Geranial \\
\hline \multirow{2}{*}{\multicolumn{2}{|c|}{$\begin{array}{l}\text { Yemen citron* } \\
\text { Spadifora cv.* }\end{array}$}} & 0.54 & 14.47 & 28.51 & 9.12 \\
\hline & & 1.92 & 22,28 & 38.70 & 12.06 \\
\hline \multicolumn{2}{|c|}{ Mexican $\lim \theta^{*}$} & 1.59 & 24.76 & 33.72 & 6.21 \\
\hline \multicolumn{2}{|c|}{ Eureka lemon $\dagger$} & 1.19 & 18.81 & 25.44 & 6.39 \\
\hline \multicolumn{2}{|c|}{ Lisbon lemon $\dagger$} & 1.23 & 20.30 & 25.05 & 6.02 \\
\hline \multirow[t]{20}{*}{$6 \mathrm{E}$} & $\quad 4$ & 0.93 & 15.28 & 25.77 & 9.06 \\
\hline & & 2.03 & 12.29 & 19.33 & 3.54 \\
\hline & & 1.16 & 14.51 & 23.20 & 8.91 \\
\hline & & 1.66 & 23.16 & 33.83 & 11.94 \\
\hline & 5, & 0.78 & 25.25 & 32.66 & 8.77 \\
\hline & & 1.30 & 22.49 & 35.97 & 5.30 \\
\hline & & 2.05 & 16.56 & 19.80 & 3.30 \\
\hline & & 1.23 & 10.08 & 14.61 & 3.21 \\
\hline & & 2.20 & 22.80 & 31.27 & 7.86 \\
\hline & & 2.52 & 13.24 & 24.87 & 5.56 \\
\hline & 6, & 0.97 & 27.89 & 30.13 & 5.95 \\
\hline & & 2.37 & 16.55 & 26.23 & 2.76 \\
\hline & & 1.46 & 22.53 & 28.39 & 7.56 \\
\hline & & 2.02 & 17.04 & 33.54 & 6.45 \\
\hline & & 0.70 & 9.24 & 14.13 & 4.12 \\
\hline & 7 & 1.29 & 18.00 & 21.31 & 4.68 \\
\hline & & 2.02 & 16.31 & 31.69 & 9.76 \\
\hline & & 1.64 & 8.20 & 16.43 & 4.05 \\
\hline & & 0.83 & 21.06 & 29.06 & 9.51 \\
\hline & 8, & 1.20 & 13.15 & 20.56 & 5.51 \\
\hline \multirow[t]{14}{*}{11} & D 30 , & 4.29 & 19.48 & 32.28 & 8.86 \\
\hline & & 3.11 & 19.11 & 28.22 & 6.83 \\
\hline & 31 & 1.29 & 21.36 & 31.01 & 6.53 \\
\hline & & 2.32 & 17.01 & 25.86 & 5.92 \\
\hline & & 2.10 & 14.36 & 20.21 & 11.09 \\
\hline & 1 & 2.80 & 16.33 & 26.65 & 6.57 \\
\hline & 32 & 1.35 & 19.40 & 24.41 & 7.07 \\
\hline & & 1.75 & 18.01 & 31.13 & 10.50 \\
\hline & 33, & 1.87 & 18.55 & 24.82 & 5.60 \\
\hline & & 1.48 & 20.49 & 24.38 & 5.72 \\
\hline & 34, & 2.21 & 19.80 & 32.18 & 10.80 \\
\hline & & 1.73 & 20.46 & 30.53 & 8.32 \\
\hline & & 2.02 & 8.94 & 23.96 & 10.90 \\
\hline & & 2.81 & 17.46 & 26.65 & 10.75 \\
\hline \multirow[t]{6}{*}{11} & D 35 , & 3.20 & 16.25 & 25.15 & 5.95 \\
\hline & 1 & 2.22 & 13.64 & 23.89 & 7.87 \\
\hline & 36 & 1.86 & 19.07 & 24.22 & 5.20 \\
\hline & & 2.02 & 19.62 & 26.91 & 8.39 \\
\hline & & 3.02 & 23.16 & 40.65 & 12.38 \\
\hline & & 2.38 & 14.14 & 26.69 & 12.88 \\
\hline \multicolumn{2}{|c|}{ C. hystrix ${ }^{\star}$} & 0.12 & 0.35 & 0.27 & 0.46 \\
\hline \multicolumn{2}{|c|}{ C. macroptera } & 0.015 & 0.34 & 0.05 & 0.15 \\
\hline
\end{tabular}

* Related taxa.

$\dagger$ Parental taxa.

All others are hybrid taxa. 
APPENDIX TABLE B

AVERAGE PERCENTAGES OF RIND-OIL COMPONENTS IN LEMON HYBRIDS, THEIR PARENTS, AND POSSIBLE ANCESTRAL TYPES

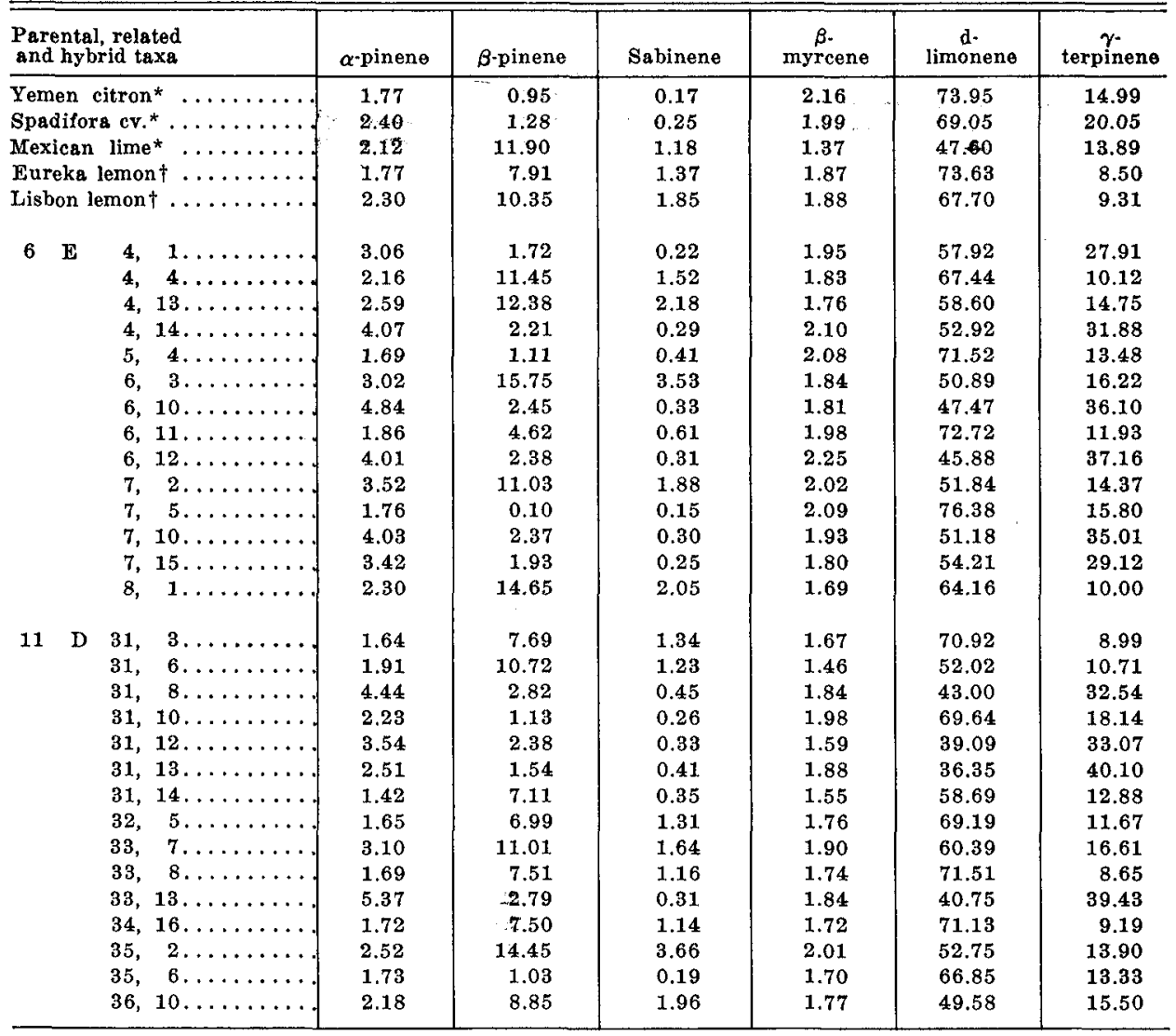

* Related taxa.

+ Parental taxa.

All others are hybrid taxa. 
Table B (Cont.)

AVERAGE PERCENTAGES OF RIND-OIL COMPONENTS IN LEMON HYBRIDS, THEIR PARENTS, AND POSSIBLE ANCESTRAL TYPES

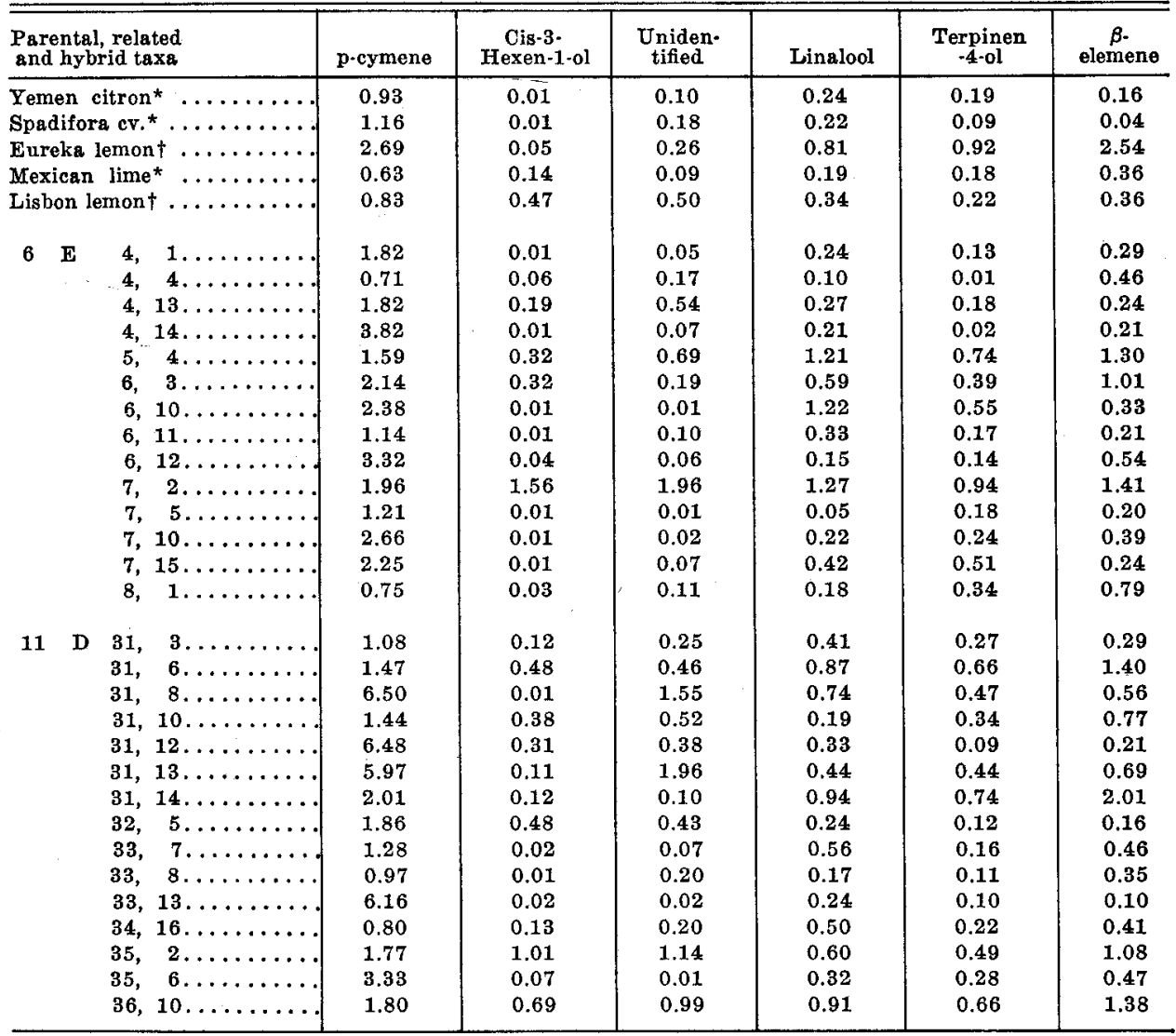

* Related taxa.

$\dagger$ Parental taxa.

(All others are hybrid taxa.) 
Table B (Cont.)

AVERAGE PERCENTAGES OF RIND-OIL COMPONENTS IN LEMON HYBRIDS, THEIR PARENTS, AND POSSIBLE ANCESTRAL TYPES

\begin{tabular}{|c|c|c|c|c|c|c|c|}
\hline \multicolumn{2}{|c|}{$\begin{array}{l}\text { Parental, related } \\
\text { and hybrid taxa }\end{array}$} & $\begin{array}{c}\text { Caryo: } \\
\text { phyllene }\end{array}$ & $a$-terpineol & Neral & Citronellol & Geranial & Nerol \\
\hline \multirow{2}{*}{\multicolumn{2}{|c|}{$\begin{array}{l}\text { Yemen citron* } \\
\text { Spadifora cv.* }\end{array}$}} & 0.20 & 0.34 & 1.56 & 0.26 & 1.73 & 0.25 \\
\hline & & 0.04 & 0.34 & 1.17 & 0.22 & 1.24 & 0.15 \\
\hline \multicolumn{2}{|c|}{ Mexican lime* } & 0.36 & 0.53 & 9.75 & 1.04 & 2.57 & 0.30 \\
\hline \multicolumn{2}{|c|}{ Eureka lemon $\dagger$} & 0.08 & 0.36 & 1.12 & 0.57 & 1.11 & 0.14 \\
\hline \multicolumn{2}{|c|}{ Lisbon lemon $\dagger$} & 0.30 & 0.48 & 1.06 & 0.88 & 1.54 & 0.17 \\
\hline \multirow[t]{14}{*}{$6 \mathrm{D}$} & $4, \quad 1$. & 0.05 & 0.30 & 1.21 & 1.85 & 1.15 & 0.03 \\
\hline & $4,4$. & 0.12 & 0.32 & 1.16 & 0.89 & 1.34 & 0.10 \\
\hline & 4,13 . & 0.22 & 0.34 & 1.33 & 1.32 & 1.17 & 0.02 \\
\hline & 4,14 & 0.04 & 0.42 & 0.58 & 0.49 & 0.61 & 0.03 \\
\hline & $5,4$. & 0.57 & 0.27 & 0.49 & 1.40 & 0.86 & 0.18 \\
\hline & $6, \quad 3$. & 0.37 & 0.16 & 1.24 & 0.96 & 1.60 & 0.29 \\
\hline & 6,10 . & 0.24 & 0.17 & 0.38 & 0.51 & 1.11 & 0.01 \\
\hline & $6,11$. & 0.21 & 0.07 & 0.50 & 1.88 & 1.20 & 0.37 \\
\hline & 6,12 . & 0.02 & 0.11 & 1.54 & 0.24 & 1.63 & 0.11 \\
\hline & 7,2 . & 0.82 & 0.16 & 1.47 & 1.30 & 1.86 & 0.09 \\
\hline & $7,5$. & 0.09 & 0.01 & 0.45 & 0.40 & 0.17 & 0.01 \\
\hline & 7,10 . & 0.04 & 0.06 & 0.88 & 0.06 & 0.64 & 0.03 \\
\hline & 7,15 . & 0.07 & 0.02 & 0.72 & 1.74 & 2.65 & 0.67 \\
\hline & $8,1$. & 0.08 & 0.06 & 1.26 & 0.96 & 0.39 & 0.15 \\
\hline \multirow[t]{15}{*}{$11 \mathrm{D}$} & $31,3$. & 0.29 & 0.68 & 1.37 & 1.12 & 1.77 & 0.15 \\
\hline & $31,6$. & 0.64 & 0.94 & 5.51 & 3.76 & 5.49 & 0.25 \\
\hline & 31,8 . & 0.43 & 0.73 & 1.15 & 0.70 & 1.68 & 0.25 \\
\hline & 31,10 & 0.04 & 0.08 & 0.60 & 0.64 & 2.01 & 0.08 \\
\hline & 31,12 & 0.37 & 0.10 & 1.28 & 1.69 & 8.57 & 0.10 \\
\hline & 31,13 . & 0.66 & 0.36 & 1.18 & 1.98 & 2.86 & 0.46 \\
\hline & 31,14 . & 0.63 & 0.20 & 4.11 & 2.33 & 4.37 & 0.35 \\
\hline & $32, \quad 5$. & 0.15 & 0.04 & 0.78 & 1.23 & 1.64 & 0.26 \\
\hline & $33,7$. & 0.07 & 0.71 & 0.43 & 0.55 & 0.71 & 0.24 \\
\hline & $33,8$. & 0.21 & 0.07 & 0.62 & 2.02 & 2.92 & 0.01 \\
\hline & 33,13 & 0.13 & 0.24 & 0.16 & 0.98 & 1.27 & 0.02 \\
\hline & 34,16 . & 0.45 & 0.80 & 1.03 & 0.99 & 2.02 & 0.03 \\
\hline & 35,2 . & 0.14 & 0.23 & 1.65 & 0.64 & 1.48 & 0.39 \\
\hline & 35,6 . & 0.52 & 0.56 & 2.10 & 2.90 & 4.48 & 0.04 \\
\hline & 36,10 & 0.76 & 1.42 & 4.15 & 2.30 & 4.46 & 0.59 \\
\hline
\end{tabular}

* Related taxa.

$\dagger$ Parental taxa.
All others are hybrid taxa. 